\title{
Role of urodynamics in evaluation of lower urinary tract dysfunction in women of pelvic organ prolapse
}

\author{
Neha Khatik ${ }^{1 *}$, Ratna Biswas ${ }^{2}$ \\ ${ }^{1}$ Department of Obstetrics and Gynecology, Shyam Shah Medical College and Sanjay Gandhi Hospital, Rewa, Madhya \\ Pradesh, India \\ ${ }^{2}$ Department of Obstetrics and Gynecology, Lady Hardinge Medical College and Smt. Sucheta Kriplani Hospital New \\ Delhi, India
}

Received: 06 July 2020

Accepted: 05 August 2020

\section{*Correspondence:}

Dr. Neha Khatik,

E-mail: neha0276@gmail.com

Copyright: ( ) the author(s), publisher and licensee Medip Academy. This is an open-access article distributed under the terms of the Creative Commons Attribution Non-Commercial License, which permits unrestricted non-commercial use, distribution, and reproduction in any medium, provided the original work is properly cited.

\section{ABSTRACT}

Background: Utero-vaginal prolapse is a common gynecological disorder, result from weakness of musculoskeletal structure that support the pelvic organ. Although it is not an emergency situation but severely affect the quality of life. Women with utero-vaginal prolapse may present with lower urinary tract dysfunction but association of urological changes with UV prolapse and beneficial effect of surgery on these changes is still debatable. Urodynamic study such as cystometry and uroflowmetry help in better understanding of lower urinary tract dysfunction and assist to plan appropriate surgical management thereby reduce chances of postoperative voiding dysfunction.

Methods: A total of 30 women of pelvic organ prolapse with lower urinary tract dysfunction, over a period of one year, were subjected to urodynamic studies after thorough evaluation by history, examination and standardized questionnaire both pre and post operatively and data analysed.

Results: In present study, urodynamic study identified urinary dysfunction in $93.34 \%$ of women recruited in study. Obstruction was present in $36.67 \%$ of women. Detrusor overactivity along with obstruction was seen in $20.00 \%$ of women. Urodynamic stress incontinence and urodynamic stress incontinence along with obstruction was identified in $13.33 \%$ of women each and detrusor overactivity was observed in $10.00 \%$ of women.

Conclusions: In present study it was found that, if surgical management of pelvic organ prolapse is planned according to urodynamic study, it will improve urologic profile of patients. To conclude that urodynamic study should be an integral part of diagnostic work up of uterovaginal prolapse patients require larger sample size and at least 6 months follow-up duration after surgery.

Keywords: Detrusor overactivity, Lower urinary tract dysfunction, Stress urinary incontinence, Urodynamic study, Utero-vaginal prolapse

\section{INTRODUCTION}

Pelvic organ prolapse is a process in which the pelvic contents, including the reproductive organ, bladder, rectum and/or small intestine become herniated through defect in vaginal wall. Pelvic organ prolapse is a health concern affecting millions of women worldwide. Prolapse affects progressively a larger percentage of women as age advances. Incidence of prolapse doubles with each decade of life between 20 and 59 years of age. ${ }^{1}$ Each year of increasing age is associated with a $12 \%$ increase in the risk of development of prolapse. ${ }^{2}$ In a study conducted in United States by Oslen et al observed that a woman has an estimated lifetime risk of $11 \%$ to undergo surgery for prolapse or incontinence. ${ }^{3}$

High parity, low estrogen status following menopause, obesity, smoking, constipation and obstetric factors 
related to individual delivery such as prolonged second stage or poor surgical repair of perineal injury are risk factors for development of pelvic organ prolapse. ${ }^{4-6}$

International continence society committee on standardization of terminology of pelvic organ prolapse and pelvic floor dysfunction has enumerated various urinary symptoms that are associated with pelvic organ prolapse. $^{7}$

Lower urinary symptoms divided into 3 groups, storage, voiding and post micturition symptoms. Storage symptoms include frequency, urgency, stress urinary incontinence and urge urinary incontinence. Voiding symptoms include hesitancy, slow stream, intermittent stream and straining. Post micturition symptoms include feeling of incomplete emptying and post micturition dribble.

There is complex relationship between pelvic organ prolapse and urinary symptoms.

Anterior vaginal wall supports the bladder and urethra directly and loss of this support results in urethral hypermobility and cystocele formation which is thought to contribute to the development of stress urinary incontinence. Literature indicates that many women with mild prolapse have stress urinary incontinence. In contrast patients with advanced prolapse commonly do not have urinary incontinence but are more likely to have obstructive symptoms due to distortion of lower urinary tract. In women with more advanced pelvic organ prolapse the stress incontinence may be occult due to compressive effect or urethral kinking and may manifest when prolapse is reduced. ${ }^{8}$

Symptoms like frequency, urgency or urge incontinence may be unrelated to prolapse and require alternate therapy, although some studies have found a positive correlation between urge incontinence and both anterior and posterior vaginal wall prolapse. Overactive bladder symptoms may be due to descent of trigone with the anterior wall prolapse or obstruction of the urethra due to vaginal wall prolapse and bladder over activity may be a counteractive mechanism to overcome the obstruction. ${ }^{9,10}$

Urodynamic studies assess the function of the bladder and urethra and are often useful in the assessment and diagnosis of patients presenting with lower urinary tract dysfunction. Urodynamic tests such as cystometry, uroflowmetry, pressure flow studies provide objective information regarding the normal and abnormal function of the urinary tract and pelvic floor, and therefore a better understanding of the cause of lower urinary tract dysfunction.

According to the recommendations of the International continence society, a urodynamic investigation should be a part of the diagnostic work up in patients with genital prolapse grade 2 or more, who are candidates for surgical correction.

Concealed stress urinary incontinence following the reduction of pelvic organ prolapse has been reported. Incorporation of urodynamic investigation in the standard diagnostic work-up of all women with symptoms of lower urinary tract dysfunction or with major degree of prolapse undergoing surgical correction helps to plan the surgical management and perform any additional surgical procedure if needed thereby reducing the chance of postoperative voiding dysfunction. With this background, this study is planned to know the role of urodynamic study in evaluation of lower urinary tract dysfunction in women of uterovaginal prolapse and analyse the postoperative with the preoperative urodynamic findings.

\section{Aims and objectives}

Aims and objectives were to study the lower urinary tract dysfunction by urodynamic study in cases of uterovaginal prolapse with lower urinary tract symptoms and in advanced degree of utero-vaginal prolapse and decide the surgical management accordingly and to analyse the postoperative outcome with the preoperative urodynamic findings in utero-vaginal prolapse.

\section{METHODS}

The present study was a hospital based observational study done on 30 patients who visited to gynecology OPD of Lady Hardinge Medical College New Delhi, from November 2011 to March 2013. The study included all women with pelvic organ prolapse who have complaints of lower urinary tract dysfunction or advanced degree (stage 3 and 4) of prolapse. Women who undergone incontinence procedure earlier or had neurological disease like multiple sclerosis and spinal cord injuries were excluded from the study.

After admission a thorough history and examination of the patient was carried out. A standardized questionnaire was given to patient to evaluate the symptoms of stress urinary incontinence, urge urinary incontinence and obstructive symptoms. This was followed by clinical staging of pelvic organ prolapse by ICS POP Q Staging and ultrasound examination was also carried out to rule out any pelvic pathology. Lower urinary tract dysfunction was evaluated by urodynamic study and then corrective procedures for uterovaginal prolapse were undertaken. Women were followed-up with same questionnaire and clinical examination and urodynamics after 2 months of corrective surgery.

\section{Urodynamic studies}

Urodynamic studies carried out in all 30 patients with pelvic organ prolapse were as uroflowmetry, cystometry. 
After obtaining sterile urine culture, 1-day voiding dairy and prophylactic antibiotic was given to patients.

\section{Uroflowmetry}

Gravimetric method was used. Maximum flow rate, average flow rate, voided volume and residual urine was measured. Maximum flow rate $\leq 15 \mathrm{ml} / \mathrm{sec}$, and/or residual urine of more than $50 \mathrm{ml}$ or $10 \%$ of voided volume in a bladder filled with a minimum of $150 \mathrm{ml}$ was taken as cut off to detect abnormal voiding. ${ }^{11,12}$

\section{Cystometry}

The following parameters were taken as normal bladder function. Residual urine of less than $50 \mathrm{ml}$ or $10 \%$ of voided volume. First desire to void between 150 and 200 ml. Capacity (taken as strong desire to void) of greater than $400 \mathrm{ml}$. Detrusor pressure rise on filling of less than $15 \mathrm{~mm} \mathrm{H}_{2} \mathrm{O}$ per $500 \mathrm{ml}$ infused. Absence of systolic detrusor contractions. No leakage on coughing. No significant pain on filling. A detrusor pressure rises on voiding (maximum voiding pressure) of less than $50 \mathrm{~cm}$ $\mathrm{H}_{2} \mathrm{O}$, with a peak flow rate of more than $15 \mathrm{ml} / \mathrm{s}$ for a voided volume over $150 \mathrm{ml}$. Urodynamic stress incontinence was diagnosed when urethral leakage was seen with increased abdominal pressure, in the absence of detrusor contractions. ${ }^{7}$

Detrusor overactivity was diagnosed when the patient has involuntary detrusor contractions during filling with or without leakage which may be spontaneous or provoked. ${ }^{7}$

\section{Statistical analysis}

Mean and standard deviation were calculated for all continuous variables and the paired t-test and ANOVA were used to determine statistically differences.

\section{RESULTS}

The age of the women recruited in this study was between 36-64 years. The mean age was 51.63 \pm 7.85 . Only 2 women $(6.67 \%)$ were below 40 years, whereas 20 women $(66.66 \%)$ were between $40-60$ years and 8 women $(26.67 \%$ ) were above 60 years of age (Table 1$)$.

All women recruited in this study were multiparous and parity ranging between 3-7. The mean parity was $4.83 \pm 1.02$. $63.33 \%$ women were with parity 5 or more, $26.67 \%$ women were with parity 4 and $10.00 \%$ of women were with parity 3 (Table 2 ).

Maximum number of women $(70.00 \%)$ recruited in this study were in stage 3 prolapse, $23.33 \%$ of women were in stage 2 prolapse and $6.67 \%$ of women were in stage 1 prolapse (Table 4).
Table 1: Age distribution in study population.

\begin{tabular}{|lll|}
\hline Age (in years) & Number of patients & Percentage \\
\hline$<\mathbf{4 0}$ & 2 & 6.67 \\
\hline $\mathbf{4 0 - 5 0}$ & 7 & 23.33 \\
\hline $\mathbf{5 0 - 6 0}$ & 13 & 43.33 \\
\hline$>\mathbf{6 0}$ & 8 & 26.67 \\
\hline Total & 30 & 100 \\
\hline
\end{tabular}

Table 2: Parity distribution in study population.

\begin{tabular}{|lll|}
\hline Parity & Number of patients & Percentage \\
\hline $\mathbf{3}$ & 3 & 10.00 \\
\hline $\mathbf{4}$ & 8 & 26.67 \\
\hline $\mathbf{5}$ or more & 19 & 63.33 \\
\hline Total & 30 & 100 \\
\hline
\end{tabular}

Table 3: Distribution of menopausal status in study population.

\begin{tabular}{|lll|}
\hline & $\begin{array}{l}\text { Number of } \\
\text { patients }\end{array}$ & Percentage \\
\hline Premenopausal & 7 & 23.33 \\
\hline Postmenopausal & 23 & 76.67 \\
\hline Total & 30 & 100 \\
\hline
\end{tabular}

In this study 7 women $(23.33 \%)$ women were premenopausal and 23 women $(76.67 \%)$ women were postmenopausal (Table 3).

Table 4: Distribution of POP-Q stages of prolapse in study population.

\begin{tabular}{|lll|}
\hline & $\begin{array}{l}\text { Number of } \\
\text { patients }\end{array}$ & Percentage \\
\hline Stage 1 & 2 & 6.67 \\
\hline Stage 2 & 7 & 23.33 \\
\hline Stage 3 & 21 & 70.00 \\
\hline Total & 30 & 100 \\
\hline
\end{tabular}

In present study, 2 women out of 4 with SUI who were in stage $1 \mathrm{Ba}$ and had urodynamic stress incontinence but did not have detrusor overactivity underwent Trans-obturator Tape procedure.

A total 2 women who had complains of both SUI and UUI and were in stage $2 \mathrm{Ba}$ and had urodynamic stress incontinence but did not have detrusor overactivity underwent trans-obturator Tape procedure along with cystocele repair. A total 4 women out of 30 who had obstructive symptoms along with SUI and on urodynamic evaluation had obstruction and USI underwent vaginal hysterectomy and anterior colporrhaphy and posterior colpo-perineorrhaphy and bladder neck buttressing (Kelly' plication). 
Table 5: Type of surgery based on symptoms, stage and urodynamic finding in women with uterovaginal prolapse.

\begin{tabular}{|c|c|c|c|c|}
\hline Number & Symptoms & Stage of UV-prolapse & Urodynamic finding & Type of surgery \\
\hline \multirow{3}{*}{4} & SUI (2) & Stage 1BA (2) & \multirow{3}{*}{$\begin{array}{l}\text { USI (+) } \\
\text { Detrusor overactivity (-) }\end{array}$} & \multirow{2}{*}{$\begin{array}{l}\text { Trans-obturator tape } \\
\text { procedure }\end{array}$} \\
\hline & \multirow[b]{2}{*}{ SUI+UUI (2) } & \multirow[b]{2}{*}{ Stage 2BA (2) } & & \\
\hline & & & & $\begin{array}{l}\text { Trans-obturator tape } \\
\text { +cystocele repair }\end{array}$ \\
\hline 4 & $\begin{array}{l}\text { SUI+ obstructive } \\
\text { symptoms }\end{array}$ & Stage $3 \mathrm{C}$ & $\begin{array}{l}\text { USI (+) } \\
\text { Detrusor overactivity (-) } \\
\text { obstruction }\end{array}$ & $\begin{array}{l}\text { Vaginal hysterectomy } \\
\text { with PFR and bladder } \\
\text { neck buttressing }\end{array}$ \\
\hline \multirow{8}{*}{22} & Stage $2 \mathrm{C}(3)$ & Obstructive symptoms & $\begin{array}{l}\text { Obstruction (2) } \\
\text { No dysfunction (1) }\end{array}$ & \multirow{8}{*}{$\begin{array}{l}\text { Vaginal hysterectomy } \\
\text { with anterior } \\
\text { colporrhaphy and } \\
\text { posterior colpo- } \\
\text { perineorrhaphy }\end{array}$} \\
\hline & Stage 2C (1) & UUI & detrusor overactivity (1) & \\
\hline & Stage 2C (1) & $\begin{array}{l}\text { Obstructive symptoms } \\
\text { +SUI+UUI }\end{array}$ & No dysfunction (1) & \\
\hline & \multirow[b]{2}{*}{ Stage 3C (10) } & \multirow[b]{2}{*}{ Obstructive symptoms } & Obstruction (7) & \\
\hline & & & $\begin{array}{l}\text { Obstruction+detrusor } \\
\text { Overactivity (3) }\end{array}$ & \\
\hline & \multirow{2}{*}{ Stage 3C (4) } & \multirow{2}{*}{$\begin{array}{l}\text { Obstructive } \\
\text { symptoms+SUI }\end{array}$} & Obstruction (2) & \\
\hline & & & Detrusor overactivity (2) & \\
\hline & Stage 3C (3) & $\begin{array}{l}\text { Obstructive symptoms } \\
+ \text { UUI }\end{array}$ & $\begin{array}{l}\text { Obstruction+detrusor } \\
\text { Overactivity (3) }\end{array}$ & \\
\hline
\end{tabular}

A total 3 women out of 30 women had obstructive symptoms and were in stage $2 \mathrm{C}$ and on urodynamic evaluation 2 women had obstruction and 1 woman did not have any dysfunction underwent vaginal hysterectomy and anterior colporrhaphy and posterior colpo-perineorrhaphy. A total 1 woman out of 30 had complain of urge incontinence and were in stage $2 \mathrm{C}$ and had detrusor overactivity on urodynamic study underwent vaginal hysterectomy and anterior colporrhaphy and posterior colpo-perineorrhaphy.

Only 1 woman who had obstructive symptoms along with SUI and UUI both were in stage $2 \mathrm{C}$ had detrusor activity only underwent vaginal hysterectomy and anterior colporrhaphy and posterior colpo-perineorrhaphy.
A total 10 women out of 30 had obstructive symptoms and were in stage $3 \mathrm{C}$ and on urodynamic evaluation 7 had pure obstruction and 3 had detrusor overactivity underwent vaginal hysterectomy and anterior colporrhaphy and posterior colpo-perineorrhaphy.

Table 6: Comparison of symptoms pre and post-surgery.

\begin{tabular}{|lll|}
\hline Symptoms & $\begin{array}{l}\text { Pre } \\
\text { surgery }\end{array}$ & $\begin{array}{l}\text { Post } \\
\text { surgery }\end{array}$ \\
\hline Obstructive & 25 & 0 \\
\hline Stress urinary incontinence & 13 & 0 \\
\hline Urge urinary incontinence & 7 & 6 \\
\hline
\end{tabular}

Table 7: Comparison of parameters of uroflowmetry pre and post-surgery.

\begin{tabular}{|lll|lll|}
\hline \multirow{2}{*}{ Urodynamic data } & Pre-surgery & Post-surgery & SD & P-value \\
\cline { 2 - 6 } & Mean & SD & Mean & 4.11 & 0.000 \\
\hline Max. flow rate (ml/sec) & 17.93 & 4.05 & 20.97 & 1.73 & 0.191 \\
\hline Avg. flow rate (ml/sec) & 12.77 & 2.56 & 13.2 & 81.47 & 0.003 \\
\hline Voided volume & 493.33 & 93.75 & 533.67 & 7.30 & 0.001 \\
\hline Residual urine (ml) & 64.33 & 19.82 & 51.33 & & \\
\hline
\end{tabular}

A total 4 women out of 30 who had obstructive symptoms along with SUI were in stage $3 \mathrm{C}$ and on urodynamic study 2 had pure obstruction and 2 had detrusor overactivity underwent vaginal hysterectomy and anterior colporrhaphy and posterior colpoperineorrhaphy.
A total 3 women out of 30 , who had obstructive symptoms along with UUI, were in stage $3 \mathrm{C}$ and had obstruction and detrusor overactivity on urodynamic study underwent vaginal hysterectomy and anterior colporrhaphy and posterior colpo-perineorrhaphy (Table 5). 
Table 8: Comparison of cystometric parameter pre and post-surgery.

\begin{tabular}{|llllll|}
\hline \multirow{2}{*}{ Cystometry data } & Pre-surgery & Post-surgery & & P-value \\
\hline & Mean & SD & Mean & SD & 0.006 \\
\hline $\mathbf{1}^{\text {st }}$ sensation to void $(\mathbf{m l})$ & 196.33 & 68.05 & 219.67 & 68.86 & 0.171 \\
\hline $\mathbf{1}^{\text {st }}$ desire to void $(\mathbf{m l})$ & 363.67 & 82.48 & 379.33 & 76.47 & 0.233 \\
\hline Strong desire to void $(\mathbf{m l})$ & 527 & 118.85 & 541.33 & 96.69 & 0.056 \\
\hline Max. filling detrusor pressure & 13.67 & 2.97 & 12.73 & 1.84 & 0.081 \\
\hline Max. cystometric capacity $(\mathbf{m l})$ & 531.67 & 124.99 & 561.67 & 97.95 & 0.010 \\
\hline Leakage of urine & 8 & 26.66 & 0 & 0.00 & 0.010 \\
\hline Unstable contractions-PHASIC & 9 & 30.00 & 2 & 6.67 & \\
\hline
\end{tabular}

In present study 25 out of 30 women had obstructive symptoms, 13 complained stress urinary incontinence and 7 had urge urinary incontinence before surgery. Postsurgery obstructive symptoms and SUI got completely relieved. 6 women still had UUI (Table 6).

Before surgery mean maximum flow rate was17.93 \pm 4.05 $\mathrm{ml} / \mathrm{sec}$ and after surgery mean maximum flow rate was $20.97 \pm 4.41$. Before surgery mean average flow, rate was $12.77 \pm 2.56 \mathrm{ml} / \mathrm{sec}$ and after surgery mean average flow rate was $13.2 \pm 1.73 \mathrm{ml} / \mathrm{sec}$. Before surgery voided volume was $493.33 \pm 93.75 \mathrm{ml}$ and after surgery voided volume was $533.67 \pm 81.47 \mathrm{ml}$. Before surgery residual urine was $64.43 \mathrm{ml} \pm 19.82 \mathrm{ml}$ and after surgery was $51.33 \pm 7.3 \mathrm{ml}$. The change in parameters were statistically significant for maximum flow rate, voided volume and residual urine (Table 7).

Before surgery average volume of $1^{\text {st }}$ desire was $196.33 \pm 68.05 \mathrm{ml}$ and after surgery it was $219.67 \pm 68.86$ $\mathrm{ml}$. Before surgery average maximum cystometric capacity was $531.67 \pm 124.99 \mathrm{ml}$ and after surgery it was561.67 $\pm 97.95 \mathrm{ml}$. Before surgery detrusor overactivity was observed in $30 \%$ ( 9 out of 30) of patients and after surgery detrusor overactivity was observed in 6\% (2 out of 30) of patients. Before surgery urodynamic stress incontinence was present in $26.66 \%$ ( 8 out of 30 ) patients and after surgery none of the women had USI (Table 8 ).

\section{DISCUSSION}

In the present study, the mean age of women was $51.63 \pm 7.85$ years. The age group included in our study was $\geq 36$ and $\leq 64$ years. Maximum number of women $(43.33 \%)$ with uterovaginal prolapse was in age group of $50-60$ years. The incidence of utero-vaginal prolapse is known to increase as the age advances. In a study by Swift et al it was found that with each year of increasing age, the risk of development of prolapse is increased by $12 \% .^{13}$

In present study, parity ranged between 3 to 7 with an average parity of $4.83 \pm 1.02$. It was observed that $63.33 \%$ of women who were recruited in the study were grand multiparous with parity of 5 or more. Thus, it is evident that, recurrent child birth predisposes to prolapse.
In a study conducted by Hendrix et al the increased prevalence of uterine prolapse was associated with increasing parity $(\mathrm{OR}, 2.13$ for first birth and 1.10 for each subsequent birth). ${ }^{14}$

In present study, $76.67 \%$ patients were postmenopausal, average duration of menopause was $7 \pm 2.86$ years. Uterovaginal prolapse was more commonly seen in postmenopausal women. Hendrix et al conducted a study and found high prevalence of pelvic organ prolapse after menopause. ${ }^{14}$ Estrogen is essential for synthesis of collagen protein that enables the supportive tissue of pelvis to stretch and return to their normal position. Decrease estrogen level after menopause results in decrease collagen in the connective tissues. Without sufficient collagen, the tissues become more rigid and may no longer provide enough support for the pelvic organs which results in pelvic organ prolapse.

A total $70 \%$ of women recruited in the study were in stage $3,23.33 \%$ of women were in stage 2 and $6.67 \%$ of women were in stage 1 .

In present study, in 4 women who had complains of SUI, urodynamic stress incontinence was observed on urodynamic evaluation but detrusor overactivity was notably absent. On POP-Q staging, 2 women were in stage $1 \mathrm{Ba}$ and 2 women were in stage $2 \mathrm{Ba}$. Transobturator tape procedure was performed in women with stage $1 \mathrm{Ba}$ and trans-obturator tape along with cystocele repair was done in stage $2 \mathrm{Ba}$.

The 4 women who had complaints of SUI along with obstructive symptoms were in POP-Q stage-3C. On urodynamic evaluation, urodynamic stress incontinence and obstruction was observed in these women. Vaginal hysterectomy and pelvic floor repair along with bladder neck buttressing was performed in these 4 women.

Out of remaining 22 women, 5 women were in POP-Q stage $2 \mathrm{C}$ and 17 women were in stage 3C. On urodynamic evaluation, detrusor overactivity was observed in 3 women, pure obstruction was seen in 11 women and 6 women had obstruction and detrusor overactivity. Surgical procedure of choice in these 
women was vaginal hysterectomy with anterior colporrhaphy and posterior colporrhaphy.

In the present study, the mean duration of follow-up after surgery was $91.23 \pm 22.89$ days.

The surgical management was altered in 8 out of 30 $(26.66 \%)$ women in which 4 out of $30(13.33 \%)$ women underwent trans-obturator tape procedure and 4 out of 30 $(13.33 \%)$ women had a surgery like bladder neck buttressing along with vaginal hysterectomy. Rest 5 who had complaints of SUI but no urodynamic evidence of SUI, additional procedure was not performed. However, all women had appropriate colporrhaphy which subsequently resolved their symptoms.

In a study conducted by Jha et al, preoperative urodynamic study was done in $60 \%$ of patients, $53 \%$ of women had abnormal results on urodynamic, $19 \%$ had pure stress incontinence and $30 \%$ had detrusor overactivity either in isolation or as mixed incontinence. The surgical management was altered in $7 \%$ who had an additional continence procedure performed as a consequence of the UDS. Preoperative UDS changed management in $33 \%$ patients and in $7 \%$ of patients, the surgical procedure was changed. ${ }^{15}$

In women who had obstructive symptoms before surgery none of the women continued to have these symptoms after surgery. Urodynamic parameters also improved after surgery. In the preoperative group the mean value for Q-max was $17.93 \pm 4.05 \mathrm{ml} / \mathrm{s}$, whereas in the postoperative group the value was $20.97 \pm 4.11 \mathrm{ml} / \mathrm{s}$ (p-value $0.00)$. Before surgery mean voided volume was $493.33 \pm 93.75 \mathrm{ml}$ and after surgery it was $533.67 \pm 81.47$ $\mathrm{ml}$ (0.003). Before surgery residual urine was $64.33 \pm 19.82 \mathrm{ml}$ and after surgery it was $51.33 \pm 7.30 \mathrm{ml}$ (p-value 0.001).

Maximum flow rate, average flow rate and voided volume were more and residual urine was less as compares to values obtained before surgery and this difference was statistically significant. Thus, it explains that surgical correction of advanced utero-vaginal prolapse does relieve the outflow obstruction that is caused due to the urethral kinking due to the large prolapse.

None of the women who had symptoms of SUI or urodynamic SUI prior to surgery, continued to have it after surgery. In addition, in the present study there was no case of occult stress incontinence presenting in women post-surgery. This could be due a thorough evaluation of individual compartment descent by POP Q staging and voiding disorder by urodynamic study prior to surgery which helped to plan the corrective surgeries or to perform additional procedures appropriately based on the POP-Q staging and urodynamic testing. In the study 8 women with urodynamic SUI, 4 women underwent trans- obturator tape procedure and 4 had bladder neck buttressing (Kelly's plication) along with the repairs.

The reason for non- occurrence of occult-SUI postsurgery in the study group could be because, a thorough assessment of symptoms by clinical examination and urodynamic study was undertaken which helped to diagnose any voiding dysfunction which was present preoperatively and managed appropriately during surgery. However, the small sample size and short follow-up period of 2 month taken in the study may also be a reason for absence of this finding.

In a study conducted by Thorns et al it was observed that there was no increase in the incidence of SUI after pelvic surgeries especially in the first two years after surgery. ${ }^{16}$

There are various studies which support the presence of occult urinary incontinence in advanced stage of prolapse. In a study by Liang it was found that women with severe degree of prolapse rarely complain of stress urinary incontinence because of urethral kinking. But, 15$80 \%$ of these women may develop such symptoms after surgery/pessary reduction. ${ }^{17,18}$

In a study by Rosenzweig et al who performed urodynamic study on 22 clinically continent women with severe urogenital prolapse, it was found that occult incontinence disorder was present in $59 \%$ of women. ${ }^{19}$

A study was conducted by Ducey et al who performed urodynamic study on 41 women with stage 3 or 4 prolapse. Urodynamics identified 17 (41.5\%) women with occult SUI. Postoperatively 3 (7.3\%) women reported urinary incontinence: 1 with stress and 2 with urge-related symptoms. None of the women without occult SUI on urodynamics reported postoperative SUI. ${ }^{20}$

In a study conducted by Chaikin et al on 24 women referred for evaluation of advanced degree of urogenital prolapse, it was found in their study that occult sphincteric incontinence was present in $58 \%$ of women with advanced degree of urogenital prolapse. ${ }^{21}$

Therefore, further studies are needed to see the prevalence of occult stress incontinence in women with uterovaginal prolapse.

On urodynamic evaluation 9 women had detrusor overactivity preoperatively whereas only 2 women had detrusor overactivity postoperatively, this suggest that post-surgical correction of the compartmental defect had led to alleviation of obstructive symptoms, thereby leading to reduction of the detrusor overactivity which may have been present to overcome the obstruction. Detrusor overactivity had resolved in $77.77 \%$ of women after surgery.

In the present study, symptoms like frequency, urgency and urge incontinence did not improve completely after 
surgery. This could be a temporary phenomenon due to the effect of surgery and six months follow up after surgery is required to evaluate the full urodynamic impact of surgery for advanced POP and this remains one of the limitations of the present study. It is postulated that reconstructive pelvic surgery disturbs the intricate innervations of the pelvis, both somatic and autonomic and this could explain the persistence of voiding symptoms such as frequency and urgency, post operatively, in spite of the correction of the anatomical defect.

Nguyen and Bhatia retrospectively reviewed the medical records of 38 women with grade

Total 2 or greater prolapse and urge incontinence secondary to detrusor overactivity who underwent vaginal reconstructive surgery. Detrusor instability resolved after surgery in $63 \%$ of subjects after surgery. ${ }^{22}$

In a study conducted by Stanton, who performed anterior colporrhaphy with or without vaginal hysterectomy in 73 patients for prolapse with or without incontinence it was found that symptoms of urge incontinence, stress incontinence and prolapse were significantly reduced following surgery, but urodynamic data did not show any significant change. $^{23}$

\section{CONCLUSION}

To conclude our results of 30 patients, urodynamic study identified urinary dysfunction in $93.34 \%$ of women recruited in the study. Obstruction was present in $36.67 \%$ of women. Detrusor overactivity along with obstruction was seen in $20.00 \%$ of women. Urodynamic stress incontinence and urodynamic stress incontinence along with obstruction was identified in $13.33 \%$ of women each and detrusor overactivity was observed in $10.00 \%$ of women. Obstruction and detrusor overactivity were more common with advance stage and Urodynamic stress incontinence was more common with early stage of uterovaginal prolapse.

Thus, urodynamic study identified the urinary tract dysfunction objectively and modified surgical management in $26.66 \%$ of women. In present study surgical correction of stress incontinence was based on urodynamic findings which prevented over and under correction of incontinence. Urge incontinence was predominantly present in women with obstruction which disappeared in $77.77 \%$ of women postoperatively. In women with obstruction the postoperative urodynamic parameter significantly improved which was result of proper correction of various compartment defect.

Thus, available evidence suggests that if surgical management of pelvic organ prolapse is planned according to urodynamic study, it will improve urologic profile of patients. Small sample size and short follow-up period after surgery was major limitation of study. Hence to conclude that urodynamic study should be an integral part of diagnostic work up of uterovaginal prolapse patients require larger sample size and at least 6 months follow-up duration after surgery.

\section{Funding: No funding sources}

Conflict of interest: None declared

Ethical approval: The study was approved by the Institutional Ethics Committee

\section{REFERENCES}

1. Gurel H, Gurel SA. Pelvic relaxation and associated risk factors: the result of logistic regression analysis. Acta Obstet Gynecol Scand.1999;78:290-3.

2. Swift SE, Pound T, Dias JK. Case control study in the etiologic factors in the development of severe pelvic organ prolapsed. In Urogyenecol J Pelvic Floor Dysfunct. 2001;12:87-192.

3. Olsen AL, Smith VJ, Bergstrom JO, Colling JC, Clark AL. Epidemiology of surgically managed pelvic-organ prolapse and urinary incontinence... Obstet Gynecol.1997;89(4):501.

4. Mant J, Painter R, Vessey M. Epidemiology of genital prolapse: observations from the Oxford family planning association study. $\mathrm{Br} \mathrm{J}$ Obstet Gynaecol. 1997;104:579-85.

5. Chiaffarino F, Chatenoud L, Dindelli M, Meschia M, Buonaquidi A, Amiacarelli F, et al. Reproductive factors, family history, occupation and risk of urogenital prolapse. Eur J Obstet Gynecol Reprod Biol. 1999;82:63-7.

6. Handa VL, Harris TA, Ostergard DR. Protecting the pelvic floor: obstetric management to prevent incontinence and pelvic organ prolapse. Obstet Gynaecol. 1996;88:470-8.

7. Bump R, Mattiasson A, Bo K, Brubakar LP, DeLancy JO, Klarskov $\mathrm{P}$, et al. The standardization of terminology of female pelvic prolapse and pelvic floor dysfunction. Am J Obstet Gynecol. 1996;175:10-7.

8. Barber MD, Matthew D. Symptoms and outcome measures of pelvic organ prolapse. Clin Obstet Gynecol J. 2005;48(3):684-61.

9. Digesu GA, Chaliha C, Salvatore S, Hutchings A, Khullar V. The relationship of vaginal prolapse severity to symptoms and quality of life. Br J Obstet Gynecol. 2005;112(7):971-6.

10. Brading AF, Turner WH. The unstable bladder: towards a comman mechanism. $\mathrm{Br} \quad \mathrm{J}$ Urol. 1994;73(1):3-8.

11. Costanini E, Mearini E, Pajoncini C, Biscotto S, Bini $\mathrm{V}$, Porena M. Uroflowmetry in female voiding disturbances. Neurourol Urodyn. 2003;22:569-73.

12. Hubeaux K, Deffieux X, Jousse M, Amarenco G. Correlation between voiding dysfunction symptoms and uroflowmetry in women suffering from stress urinary incontinence. Indian J Urol. 2012;28(3):3137. 
13. Swift SE, Pound T, Dias JK. Case control study in the etiological factors in the development of severe pelvic organ prolapsed. Int Urogynecol J Pelvic Floor Dysfunct. 2001;12:87-192.

14. Hendrix SL, Clark A, Nygaard I, Argaki A, Barnabei $\mathrm{V}$, Mc Tiernan A. Pelvic organ prolapse in the women's health initiative: gravity and gravidiy. Am J Obstet Gynecol. 2002;186(6):1160-6.

15. Jha S, Toozs-Hobson P, Parson M, Gull F. Does preoperative urodynamics changes the management of prolapse? J Obs Gynecol. 2008;28(3):320-2.

16. Thorn BS, Brown JS. Reproductive and hormonal risk factors for urinary incontinence in later life. A review of clinical and epidemiological literature. J Amer Geriatr Soc. 1998;46:1411-7.

17. Liang CC, Chang SD, Chang YL, Tseng LH, Lo TS, Soong YK. Postsurgical urinary incontinence in continent women undergoing hysterectomy for uterine prolapse. Incont Pelvic Floor Dysfunct. 2007;2:45-8.

18. Klutke JJ, Ramos S. Urodynamic outcome after surgery for severe prolapse and potential stress incontinence. Am J Obstet Gynecol. 2000;182:13781.

19. Rosenweig BA, Pushkin S, Blumenfeld D, Bhatia NN. Prevalence of abnormal urodynamic test results in continent women with severe genitourinary prolapse. Obstet Gynecol. 1992;79:539-42.

20. Duecy EE, Pulvino JQ, Mcnanley AR, Buchsbaum GM. Urodynamic prediction of occult stress urinary incontinence before vaginal surgery for advanced pelvic organ prolapse: evaluation of postoperative outcomes. Female Pelvic Med Reconstr Surg. 2010;16:215-7.

21. Chaikin DC, Groutz A, Blaivas JG. Predicting the need for anti- incontinence surgery in continent women undergoing repair of severe urogenital prolapse. J Urol. 2000;163:531-4.

22. Nguyen JK, Bhatia NN. Resolution of motor urge incontinence after surgical repair of pelvic organ prolapse. J Urol. 2001;166:2263-6.

23. Stanton SL, Hilton P, Norton C, Cardozo L. Clinical and urodynamic effects of anterior colporrhaphy and vaginal hysterectomy for prolapse with and without incontinence. Br J Obstet Gynecol. 1982;89:459-63.

Cite this article as: Khatik N, Biswas R. Role of urodynamics in evaluation of lower urinary tract dysfunction in women of pelvic organ prolapse. Int $\mathbf{J}$ Reprod Contracept Obstet Gynecol 2020;9:3790-7. 